\title{
Editorial
}

\section{World Bank's New Focus on using ICT for Greater Development Impacts}

The World Bank has announced a new ICT strategy for projects sponsored from 2012-2015. The strategy is aimed at helping developing countries use ICT to transform delivery of basic services, drive innovation and productivity gains and improve competitiveness. The strategy builds on the Bank Group's experience working with client countries on ICT sector reforms, infrastructure development and electronic government. (see article in E-Government Developments)

Since 2000 the World Bank's has directly supported more than $\$ 2.3$ billion for ICT improvements and helped attract an estimated $\$ 30$ billion in private investment for mobile network infrastructure in the least developing countries. This new strategy can be expected to influence governments in many developing countries to design and implement ICT programs that follow the Bank's Three ICT Pillars:
- Transform - Making development more open and accountable and improving service delivery for education, health and financial services.

- Innovate - Developing competitive IT-based service industries and fostering ICT innovation across national economies.

- Connect - Scaling up affordable access to broadband, including for women, disabled and disadvantaged communities.

This new ICT focus should have far-reaching beneficial impacts on ICT advancement across the world.

Russell Pipe, Editor in Chief 